\title{
KECEMASAN PASIEN PRE OPERASI BEDAH MAYOR
}

\author{
Ridwan Kustiawan', Angga Hilmansyah² \\ ${ }^{1}$ Dosen Poltekkes Kemenkes Tasikmalaya, \\ ${ }^{2}$ Alumni Poltekkes Kemenkes Tasikmalaya
}

\begin{abstract}
Abstrak
Tujuan penelitian ini adalah mengetahui karakteristik pasien pre operatif yang meliputi jenis kelamin, umur, pendidikan, dan pekerjaan. Cemas sedang adalah lapang persepsi klien sudah terfokos pada suatu hal yang dipikirkannya. Rancangan penelitian ini adalah penelitian deskriptif dengan populasi yaitu seluruh pasien pre operasi dengan bedah mayor di Ruang Bedah 3a, 3b, dan 4 RSU Kota Tasikmalaya Tahun 2013, dari tanggal 13 Juni - 17 Juli 2013, pengambilan sampel pada penelitian ini adalah accidental sampling dengan jumlah 21 responden, hasil penelitian ini menunjukkan mayoritas tingkat kecemasan pada pasien pre operasi adalah cemas sedang (81\%). Rumah sakit diharapkan meningkatkan lagi dalam memperhatikan faktor-faktor yang berhubungan dengan tingkat kecemasan meliputi jenis kelamin, pendidikan, pekerjaan serta usia dan tingkat kecemasan pasien pre operasi untuk pengembangan asuhan keperawatan.
\end{abstract}

Kata Kunci : Bedah mayor, Kecemasan, Pre operasi

\begin{abstract}
The purpose of this research is to know pre operative patient characteristics cover gender, age, education, employment. On moderat anxiety, the client perception space already focused to something to think about. The design of this research is descriptive, population are all pre operative patient with major surgery at $3 a, 3 b$, and 4 operating room Tasikmalaya Regional Hospital 2013, from 13 until 17 of July, for the sampling method use accidental sampling with 21 respondents. The results of this research show that the pre operative patient majority suffer Moderat Anxiety (81\%). The suggestion for hospital, expected to increase the attention to factors which are related to anxiety level cover gender, education, employment, age, and attention to pre operative patient level of anxiety for nursing care development.
\end{abstract}

Keyword : Major Surgery, Anxiety, Pre operative

\section{PENDAHULUAN}

Kesehatan jiwa adalah suatu kondisi sehat emosional, psikologis dan sosial yang terlihat dari hubungan interpersonal yang memuaskan, perilaku dan koping yang efektif, konsep diri yang positif, dan kesetabilan emosional (Johnson, 1997 dalam Videbeck 2008). Prevalensi gagguan jiwa dari tahun ke tahun di berbagai Negara menunjukan angka yang cukup tinggi. WHO (World Health Organization, 2009), memperkirakan 450 juta orang di seluruh dunia mengalami gangguan mental, sekitar $10 \%$ adalah orang dewasa dan $25 \%$ penduduk diperkirakan akan mengalami gangguan jiwa pada usia tertentu selama hidupnya. Gangguan jiwa mecapai $13 \%$ dari penyakit secara keseluruhan dan kemungkinan akan berkembang menjadi $25 \%$ di tahun 2030. Menurut National Institute of Mental Health (NIMH) berdasarkan hasil sesus penduduk Amerika Serikat tahun 2004, di perkirakan $26,2 \%$ penduduk yang berusia 
18 tahun atau lebih mengalami ganngguan jiwa yang ada di Negara berkembang.

Indonesia merupakan salah satu Negara berkembang menunjukan angka gangguan jiwa yang cukup tinggi. Data hasil riset kesehatan dasar tahun 2007 yang dilakukan oleh Badan Penelitian Pengembangan Kesehatan, menunjukan prevalensi gangguan jiwa di Indonesia sebesar 4,6 permil, artinya 1000 penduduk Indonesia, maka empat sampai lima orag diantaranya menderita gangguan jiwa. Di Jawa Barat Berdasarkan Riset Kesehatan Dasar tahun 2007 ditemukan 0,2\% dari penduduk jawa barat mengalami gangguan jiwa berat, sementara gangguan mental emosional pada penduduk jawa barat mencapai $20 \%$ melampaui prevalensi secara nasional $(11,6 \%)$. Jika di anasila dari sekitar 40 juta jiwa penduduk jawa barat maka sekitar 8 juta jiwa penduduk jawa barat mengalami masalah mental emosional dan 80 ribu jiwa pernah mengalami gangguan jiwa berat.

Kesehatan jiwa memiliki banyak komponen dan dipengaruhi oleh beberapa faktor, diantaranya individu akan merasa cemas sesuai degan keadaan. Keadaan emosi ini tidak mempunyai objek yang spesifik, bersifat subjektif dan dikomunikasikan secara interpersonal. Ansietas dapat disebabkan oleh perasaan takut tidak diterima dilingkungan tertentu, pengalaman traumatis, rasa frustasi akibat kegagalan mencapai tujuan, dan ancaman terhadap intregitas diri serta konsep diri (CMHN, 2006). Ansietas atau kecemasan adalah kekhawatiran yang tidak jelas dan menyebar, berkaitan dengan perasaan tidak pasti dan tidak berdaya (Stuart dan Laraia, 2005).

Semua orang yang akan menjalani operasi yang pertama kali akan mengalami kecemasan, teutama pada saat satu hari sebelum operasi. Kecemasan merupakan suatu perasaan takut yang tidak menyenangkan dan tidak dapat dibenarkan yang sering disertai dengan gejala fisiologis, yang dirasakan oleh pasien pre operatif (David, 2003).Dampak yang mungkin muncul bila kecemasan pasien pre operatif tidak segera ditangani, yang pertama pasien dengan tingkat kecemasan tinggi tidak akan mampu berkonsentrasi dan memahami kejadian selama perawatan dan prosedur. Kedua, harapan pasien terhadap hasil, pasien mungkin sudah memiliki gambaran tersendiri mengenai pemulihan setelah pembedahan. Ketiga pasien akan merasa lebih nyaman dengan pembedahan jika pasien mengetahui momen yang dihadapi pada saat hari pembedahan tiba. Keempat, pasien mungkin memerlukan penjelasan mengenai nyeri yang akan di rasakan setelah operasi.

Suliswati, dkk (2005) menyebutkan bahwa salah satu faktor predisposisi yang dapat menyebabkan timbulnya ansietas adalash krisis yang di alami individu baik krisis perkembangan maupun krisis situasional. Kecemasan atau ansietas biasanya berhubungan dengan segala macam prosedur asing yang harus dijalani pasien dan juga ancaman terhadap keselamatan jiwa, misalkan akibat prosedur pembedahan dan tindakan pembiusan. Kecemasan pasien pre operatif disebabkan berbagai faktor, salah satunya adalah faktor pengetahuan dalam mengaplikasikan pencegahan kecemasan pada pasien pre operatif.Operasi merupakan tindakan pembedahan pada suatu bagian tubuh. Pre operatif adalah fase dimulai ketika keputusan untuk menjalani operasi atau pembedahan dibuat dan berakhir ketika pasien dipindahkan ke meja operasi. (Smeltser and Bare, 2000 dalam Kurasein 2009).Berdasarkan hal tersebut maka rumusan masalah penelitiannya adalah Bagaimana Tingkat Kecemasan pada Pasien Pre operatif di Ruang Bedah yaitu 3a, 3b dan ruang 4 RSU Kota Tasikmalaya ?.

Tujuan penelitian ini adalah diketahuinya karakteristik pasien pre operatif yang meliputi jeinis kelamin, umur, pendidikan, pekerjaan dan diketahuinya tingkat kecemasan pada pasien pre operatif 
dengan klasifikasi gawat dan darurat di Ruang Bedah di Ruang bedah yaitu 3a, 3b, dan ruang 4 RSU Kota Tasikmalaya. Sedangkan manfaat penelitian ini Diharapkan dapat memberikan manfaat khususnya untuk dapat menambah referensi perpustakaan sebagai acuan bahan penelitian yang akan datang bagi instansi pendidikan dan diharapkan juga dapat memberikan informasi bagi rumah sakit tentang faktor-faktor kecemasan pada pasien pre operasi.

\section{METODE PENELITIAN}

Penelitian ini merupakan penelitian deskriptif dengan tujuan mengetahui karakteristik pasien pre operatif yang meliputi jenis kelamin, umur, pendidikan serta pekerjaan, dengan tingkat kecemasan pasien pre operatif di Ruang Bedah meliputi 3a, 3b dan ruang 4 RSU Kota Tasikmalaya. Populasi dalam penelitian ini adalah seluruh pasien pre operasi mayor yang dirawat di Ruang Bedah yaitu 3a, 3b, dan ruang 4 Rumah Sakit Umum Kota Tasikmalaya sebanyak 21 orang dan semuanya dijadikan sampel (total sampel). Analisa data dalam penelitian ini terdiri dari analisis univariat bertujuan menggambarkan deskriptif karakteristik responden dan gambaran tingkat kecemasan pada pasien pre operatif dilakukan dengan menyajikan distribusi frekuensi dari variabel yang diteliti dan disajikan dalam bentuk tabel dan grafik untuk mengetahui proporsi masing-masing variabel yang diteliti. Standar yang digunakan Skala HARS Menurut Hamilton Anxiety Rating Scale (HARS) penilaian tingkat kecemasan.Cara Penilaian kecemasan adalah dengan memberikan nilai dengan kategori:1-4 cemas ringan, 4-8 cemas sedang, 8-12 cemas berat, dan 12-16 adalah panik.

\section{HASIL PENELITIAN}

1. Distribusi Responden Berdasarkan Jenis Kelamin

Tabel 1 menjelaskan tentang distribusi frekuensi responden pasien pre operasi berdasarkan jenis kelamin di Ruang 4, 3a dan 3b RSU Kota Tasikmalaya

Tabel 1. Distribusi Frekuensi Responden Pasien Pre Operasi Berdasarkan Jenis Kelamin

\begin{tabular}{cccc}
\hline No & $\begin{array}{c}\text { Jenis } \\
\text { Kelamin }\end{array}$ & Jumlah & $\%$ \\
\hline 1 & Laki-laki & 11 & $52.4 \%$ \\
\hline 2 & Perempuan & 10 & $47.6 \%$ \\
\hline & Total & 21 & $100 \%$ \\
\hline
\end{tabular}

2. Distribusi Responden Berdasarkan Pendidikan Terakhir

Berikut ini adalah distribusi frekuensi responden pasien pre operasi berdasarkan pendidikan di Ruang 4, 3a dan 3b RSU Kota Tasikmalaya.

Tabel 2. Distribusi Frekuensi Responden Pasien Pre Operasi Berdasarkan Pendidikan

\begin{tabular}{clcc}
\hline No & \multicolumn{1}{c}{$\begin{array}{c}\text { Pendidikan } \\
\text { Terakhir }\end{array}$} & Jumlah & $\%$ \\
\hline 1 & SD & 11 & $52.4 \%$ \\
\hline 2 & SMP & 3 & $14.3 \%$ \\
\hline 3 & SMA & 5 & $23.8 \%$ \\
\hline 4 & Perguruan Tinggi & 2 & $9.5 \%$ \\
\hline & Total & 21 & $100 \%$ \\
\hline
\end{tabular}

3. Distribusi Responden Berdasarkan Jenis Pekerjaan

Tabel ini menjelaskan tentang distribusi frekuensi responden pasien pre operasi berdasarkan pekerjaan di Ruang 4, 3a, dan 3b RSU Kota Tasikmalaya.

Tabel 3. Distribusi Frekuensi Responden Pasien Pre Operasi Berdasarkan Pekerjaan

\begin{tabular}{clcc}
\hline No & $\begin{array}{c}\text { Jenis } \\
\text { Pekerjaan }\end{array}$ & Jumlah & $\%$ \\
\hline 1 & Wirausaha & 5 & $23.8 \%$ \\
\hline 2 & Buruh & 1 & $4.8 \%$ \\
\hline 3 & Petani & 3 & $14.3 \%$ \\
\hline 4 & IRT & 7 & $33.3 \%$ \\
\hline 5 & Pelajar & 5 & $23.8 \%$ \\
\hline & Total & 21 & $100 \%$ \\
\hline
\end{tabular}


4. Distribusi Responden Berdasarkan Usia Tabel berikut ini menjelaskan distribusi frekuensi responden pasien pre operasi berdasarkan usia di Ruang 4, 3a dan 3b RSU Kota Tasikmalaya.

Tabel 4. Distribusi Frekuensi Responden Pasien Pre Operasi Berdasarkan Usia

\begin{tabular}{cccc}
\hline No & Usia & Jumlah & $\%$ \\
\hline 1 & $<20$ tahun & 1 & $4.8 \%$ \\
\hline 2 & $\begin{array}{c}20-35 \\
\text { tahun }\end{array}$ & 9 & $42.9 \%$ \\
\hline 3 & $>35$ tahun & 11 & $52.4 \%$ \\
\hline & Total & 21 & $100 \%$ \\
\hline
\end{tabular}

5. Distribusi Responden Berdasarkan Tingkat kecemasan

Berikut ini menjelaskan tentang distribusi frekuensi pasien pre operasi berdasarkan tingkat kecemasan di Ruang 4, 3a, dan 3b RSU Kota Tasikmalaya.

Tabel 5. Distribusi Frekuensi Pasien Pre Operasi Berdasarkan Tingkat Kecemasan

\begin{tabular}{|c|c|c|c|}
\hline No & $\begin{array}{c}\text { Tingkat } \\
\text { Kecemasan }\end{array}$ & Jumlah & $\%$ \\
\hline 1 & CemasRingan & 3 & $14.3 \%$ \\
\hline 2 & CemasSedang & 17 & $81.0 \%$ \\
\hline \multirow[t]{2}{*}{3} & CemasBerat & 1 & $4.8 \%$ \\
\hline & Total & 21 & $100 \%$ \\
\hline
\end{tabular}

\section{PEMBAHASAN}

\section{Tingkat Kecemasan Berdasarkan Jenis Kelamin}

Dari hasil penelitian dapat dilihat bahwa distribusi tingkat kecemasan pasien pre operasi di Ruang 4, 3a dan 3b RSU Kota Tasikmalaya lebih banyak laki-laki. Hasil penelitian ini sejalan dengan penelitian yang dilakukan oleh Sawitri dan Sudarwanto (2008) tentang pengaruh pemberian informasi pre operasi terhadap tingkat kecemasan pada pasien pre operasi mayor di ruang orthopedi RSU Islam Kustati Surakarta didapatkan responden yang banyak mengalami kecemasan adalah laki-laki sebanyak $67.2 \%$. Diperkuat dengan hasil penelitian yang dilakukan Budi santoso dengan kecemasan pasien pre operasi di RS. Islam Amal Sehat Sragen tahun 2008, sampel yang diteliti berjumlah 35 orang menunjukan tidak ada hubungan yang signifikan antara jenis kelamin dengan tingkat kecemasan.

Hal ini tidak sesuai degan teori yang dikemukakan Videbeck (2008) bahwa laki-laki dan perempuan mempunyai perbedaan tingkat kecemasan, dimana perempuan lebih mudah tersinggung, sangat peka dan menonjolkan perasaanyan. Sedangkan lakilaki memiliki karakteristik maskulin yang cenderung dominan, aktif, lebih rasional dan tidak menunjukkan perasaan. Hal serupa diungkapkan Myers (1983) dalam Kurasein 2009 mengatakan bahwa perempuan lebih cemas akan ketidakmampuannya disbanding dengan laki-laki, karena laki-laki lebih aktif, eksploratif, sedangkan perempuan lebih sensitif. Penelitian lain menunjukkan bahwa laki-laki lebih rileks dibanding perempuan. Namun pada penelitian ini menyatakan bahwa laki-laki lebih banyak mengalami kecemasan dibandingkan perempuan. Hal ini mungkin tergantung pada mekanisme koping individu tersebut dan tidak ada hubungan antara jenis kelamin dengan kecemasan pre operasi.

\section{Tingkat Kecemasan Berdasarkan Pendidikan Terakhir}

Hasil penelitian dapat dilihat bahwa distribusi tingkat kecemasan pasien pre operatif di Ruang 4, 3a dan 3b RSU Kota Tasikmalaya menggambarkan bahwa pendidikan terakhir paling banyak adalah SD. Penelitian yang serupa tentang faktor-faktor yang mempengaruhi tingkat kecemasan oleh Maryaningtyas (2005) dalam Kurasein 2009, menunjukkan bahwa faktor pendidikan adalah salah satu faktor eksternal yang dapat berkontribusi terhadap kecemasan seseorang selama di rumah sakit.

Hal ini tidak sesuai dengan Penelitian yang telah dilakukan dengan judul Hubungan Tingkat Pengetahuan Informasi Pra Bedah Dengan Tingkat Kecemasan Pasien Praoperasi yang menggambarkan bahwa 
$57,1 \%$ responden memiliki pengetahuan yang baik tentang informasi pra bedah, 92,9\% responden mengalami cemas sedang pada saat akan dilakukan operasi (Graha cendikia, 2009). Hal ini menunjukan tidak semua responden yang memiliki pengetahuan tinggi tidak mengalami kecemasan begitu juga responden yang memiliki pengetahuan pra bedah kurang akan mengalami kecemasan berat.

Hal ini tergantung terhadap persepsi atau penerimaan responden itu sendiri terhadap operasi yang akan dijalankannya, mekanisme pertahanan diri dan mekanisme koping yang digunakan. Pada sebagian orang yang mengetahui informasi pra bedah secara baik justru akan meningkatkan kecemasannya, dan sebaliknya pada responden yang mengetahui informasi pra bedah yang minim justru membuatnya santai menghadapi operasinya, karena menurut Asmadi (2008) setiap ada stresor yang menyebabkan individu merasa cemas maka secara otomatis muncul upaya untuk mengatasinya dengan berbagai mekanisme koping.

\section{Tingkat Kecemasan Berdasarkan Pekerjaan}

Hasil penelitian dapat dilihat bahwa distribusi tingkat kecemasan pasien pre operatif berdasarkan pekerjaan di Ruang 4, 3a dan 3b RSU Kota Tasikmalaya bahwa IRT merupakan jenis pekerjaan terbanyak. Hal ini sesuai dengan dengan teori yang dikemukakan Maryaningtyas (2005) dalam Kurasein 2009 diketahui bahwa pekerjaan berpengaruh terhadap kecemasan. Teori ini dikuatkan dalam penelitian, bahwa faktor pekerjaan adalah salah satu faktor yang dapat berkontribusi terhadap timbulnya kecemasan.

Tetapi hal ini tidak serupa dengan teori yang dinyatakan oleh Kusmarjathi (2009) dalam Santoso (2009) bahwa jenis pekerjaan di swasta yang mempunyai penghasilan tidak menentu dapat mempengaruhi perilaku responden dalam menentukan pengobatan, membeli obat, biaya perawatan di rumah sakit, dan biaya pengobatan yang tinggi dapat menambah tingkat kecemasan responden. Pekerjaan dapat mempengaruhi tingkat kecemasan hal ini mungkin dipengaruhi oleh beberapa hal, misalnya pengalaman kerja serta wawasan tentang pengetahuan yang berhubungan dengan faktor kecemasan.

\section{Tingkat Kecemasan Berdasarkan Usia}

Dari hasil penelitian dapat dilihat bahwa distribusi tingkat kecemasan pasien pre operatif berdasarkan usia di Ruang 4, 3a dan 3b RSU Kota Tasikmalaya menggambarkan bahwa usia > 35 tahun paling banyak. Kusmarjathi (2009) dalam Santoso (2009), mengemukakan hal yang serupa bahwa kematangan usia berpengaruh terhadap seseorang dalam menyikapi situasi atau penyakitnya dalam mengatasi kecemasan yang dialami. Hal ini sesuai dengan yang dikemukakan oleh Lutfa (2008) dalam Santoso (2009) bahwa gangguan kecemasan dapat terjadi pada semua usia, namun lebih sering pada usia dewasa karena banyak masalah yang dihadapi.

Kaplan \& Sadock (1997) dalam Videbeck (2008) juga mengungkapkan hal yang serupa bahwa usia merupakan salah satu faktor internal yang berkontribusi terhadap timbulnya kecemasan pada orang tua. Dikaitkan dengan kecemasan, Nugroho dalam Purba (2011) mengemukakan bahwa masalah fisik dan psikologis sering ditemukan pada lanjut usia, masalah psikologis diantaranya perasaan cemas. Umur berkorelasi dengan pengalaman, pengalaman berkorelasi dengan pengetahuan, pemahaman dan pandangan terhadap suatu penyakit atau kejadian sehingga akan membentuk persepsi dan sikap. Sehingga umur tidak ada hubungannya dengan faktor kecemasan.

Kematangan dalam proses berpikir pada individu yang berumur dewasa lebih memungkinkannya untuk menggunakan mekanisme koping yang baik dibandingkan kelompok umur anak-anak, ditemukan sebagian besar kelompok umur anak yang 
mengalami insiden fraktur cenderung lebih mengalami respon cemas yang berat dibandingkan kelompok umur dewasa. Hal ini mungkin bisa saja terjadi pada setiap individu dikarenakan persepsi mekanisme koping individu tersebut terhadap persepsi atau penerimaan yang mempengaruhinya.

\section{Tingkat Kecemasan Pasien Pre Operatif}

Hasil penelitian ini menunjukkan bahwa tingkat kecemasan pasien pre operatif yang paling banyak berada pada kecemasan sedang, namun ada sebagian kecil yang mengalami kecemasan ringan dan berat. Hal ini serupa dengan hasil penelitian yang dilakukan Makmuri et.al dalam Sawitri dan Sudaryanto (2008) tentang tingkat kecemasan pasien pre operasi fraktur femur di RS Prof. Dr. Margono Soekarjo Purwokerto menunjukan bahwa dari 40 orang responden terdapat 16 orang $(40 \%)$ mengalami tingkat kecemasan dalam kategori sedang. Hal ini dikarenakan respon cemas seseorang tergantung pada kematangan pribadi, pemahaman dalam menghadapi tantangan, harga diri, dan mekanisme koping yang digunakan (Stuart and Laraia, 2005). Penelitian ini tidak sesuai dengan penelitian yang dilakukan oleh Hendri (2009) dalam Santoso (2009) dengan sampel 38 orang, menunjukan bahwa sebagian besar responden mengalami tingkat kecemasan ringan $(44,7 \%)$ kecemasan sedang (28.9\%) dan kecemasan berat $(26,3 \%)$.

Menurut Peplau dalam Suliswati (2005), individu yang mengalami kecemasan sedang terfokus hanya pada pikiran yang menjadi perhatiannya, terjadi penyempitan lapangan persepsi, masih dapat melakukan sesuatu dengan arahan orang lain. Sedangkan individu yang mengalami kecemasan ringan masih waspada serta lapang persepsinya meluas, menajamkan indra. Dapat memotivasi individu untuk belajar dan mampu memecahkan masalah serta efektif dan menghasilkan pertumbuhan dan kreatifitas. Namun individu yang mengalami kecemasan berat dengan ciri lapang persepsi individu sangat sempit. Pusat perhatiannya pada detil yang kecil (spesifik) dan tidak dapat berpikir tentang hal-hal lain. Seluruh perilaku dimaksudkan untuk mengurangi kecemasan dan perlu banyak perintah/arahan untuk terfokus pada area lain. Dalam penelitian ini individu yang mengalami kecemasan berat sebanyak satu orang yang berusia kurang dari 20 tahun, sehingga diperlukan penanganan yang lebih spesifik. Kematangan dalam proses berpikir pada individu yang berumur dewasa lebih memungkinkannya untuk menggunakan mekanisme koping yang baik dibandingkan kelompok umur anak-anak.

\section{KESIMPULAN}

Kecemasan pasien pre operasi berdasarkan jenis kelamin menunjukkan tingkat kecemasan sedang (52.40\%), berdasarkan pendidikan (52.40\%), berdasarkan jenis pekerjaan (33.30\%), berdasarkan usia > 35 tahun $(52.40 \%)$. Tingkat kecemasan pasien pre operasi di Ruang 3a, 3b, dan 4 RSU Kota Tasikmalaya yang paling banyak adalah kecemasan sedang, ada juga yang mengalami kecemasan ringan dan sebagian kecil mengalami kecemasan berat.

\section{DAFTAR PUSTAKA}

Asmadi. (2008). Kebutuhan Dasar Manusia. Jakarta: Salemba Medika.

Badan Penelitian dan Pengembangan Kesehatan Kementrian Kesehatan RI. (2007). Riset Kesehatan Dasar (Riskesdas). Jakarta.

CMHN (2006). Modul Basic Course Community Mental Health Nursing. Jakarta : WHO FIK UI.

David A. (2003). Buku Saku Psikiatri. Edisi 6. Jakarta: EGC.

Doenges. (2006). Psychiatric plans : Guidelines for Individualisting Care. $\left(3^{\text {th }}\right.$ ed). Philadelphia : F.A Davis.

Kurasein, D. (2009). Faktor-faktor yang Berhubungan dengan Tingkat 
Kecemasan Pasien yang akan Menjalani Operasi Mayor Elektif di Ruang Rawat Bedah RSUP Fatmawati. Jakarta Selatan.

Purba, T.S. (2011). Gambaran Tingkat Kecemasan Pasien Pre Operasi. Tasikmalaya.

Stuart, GW., and Laraia, M.T. (2005). Principles and practices of psychiatric nursing. $\left(8^{\text {th }}\right.$ ed). St. Louis : Mosby Year B

Santoso B. (2009). Hubungan Antara Karakteristik Demografi dengan Kecemasan Pasien Pra Operasi Di Rumah Sakit Islam Amal Sehat Sragen tahun 2008. http://skripsistikes.wordpress.com.

Diakses pada tanggal 26 Oktober 2009

Sawitri, E, \& sudaryanto, A. (2008). Pengaruh Pemberian Informasi Pre Operasi Terhadap Tingkat Kecemasan pada Pasien Pre Operasi Mayor di Ruang Orthopedic RSU Islam Kustati Surakarta.http://jurnal.pdii.lipi.go.id/admin /jurnal/11081318.pdf. Diperoleh tanggal 22 Juli 2013.

Suliswati, dkk (2005). Konsep Dasar Keperawatan Kesehatan Jiwa. Jakarta : EGC

Videbeck, S. (2008). Buku Ajar Keperawatan Jiwa. Jakarta : EGC

WHO. (2009). Improving Health System and Service for Mental Health : WHO Library cataloguing-in-Publication Data. 